\title{
FAKTOR-FAKTOR YANG MEMPENGARUHI MOTIVASI DALAM BERWIRAUSAHA PADA MAHASISWA PENDIDIKAN EKONOMI UNDIKSHA
}

\author{
I Gede Krisna Mahardika ${ }^{1}$, Iyus Akhmad Haris², Made Ary Meitriana ${ }^{3}$ \\ Jurusan Pendidikan Ekonomi \\ Universitas Pendidikan Ganesha \\ Singaraja, Indonesia \\ e-mail: krisnamahardika516@yahoo.co.id¹, iyus.haris@gmail.com², \\ ary.meitriana@yahoo.co.id ${ }^{3}$
}

\begin{abstract}
Abstrak
Tujuan penelitian ini adalah untuk mengetahui faktor yang mempengaruhi motivasi mahasiswa Jurusan Pendidikan Ekonomi Undiksha untuk berwirausaha dan faktor yang dominan mempengaruhi motivasi mahasiswa Jurusan Pendidikan Ekonomi Undiksha untuk berwirausaha. Jenis penelitian ini adalah penelitian kuantitatif dengan menggunakan rancangan penelitian faktorial. Subjek penelitian ini adalah mahasiswa Jurusan Pendidikan Ekonomi FE Undiksha yang berwirausaha sebanyak 31 orang. Pengumpulan data menggunakan kuesioner, yang selanjutnya dianalisis dengan analisis faktor berbantuan program SPSS 24.0 for Windows. Hasil penelitian menunjukkan bahwa faktor yang mempengaruhi motivasi mahasiswa Jurusan Pendidikan Ekonomi FE Undiksha untuk berwirausaha adalah faktor laba dengan eigenvalue sebesar 0,734 , nilai varian sebesar $18,353 \%$, faktor kebebasan memiliki eigenvalue sebesar 1,926 dengan nilai varian sebesar $48,153 \%$, faktor impian personal memiliki eigenvalue sebesar 1,007 dengan nilai varian sebesar $25,175 \%$, dan faktor kemandirian memiliki eigenvalue sebesar 0,333 dengan nilai varian sebesar $8,319 \%$. Faktor yang paling dominan mempengaruhi motivasi mahasiswa Jurusan Pendidikan Ekonomi FE Undiksha untuk berwirausaha adalah faktor kebebasan dengan varimax rotation sebesar $48,153 \%$.
\end{abstract}

Kata kunci: motivasi berwirausaha, analisis faktor.

\section{Abstract}

The purpose of this research was to determine the factors that influence the motivation of Undiksha Economics Education Department students for entrepreneurship and the dominant factors affecting the motivation of Undiksha Economics Education Department students for entrepreneurship. This type of research is quantitative research using a factorial research design. The subjects of this study were 31 students of Undiksha Economics Education Department who were self-employed. Data collection uses questionnaires, which are then analyzed by factor analysis assisted by SPSS 24.0 for Windows. The results showed that the factors that influence the motivation of Undiksha Economic Education students for entrepreneurship are eigenvalue profit factor of 0.734 , variant value of $18.353 \%$, freedom factor has an eigenvalue of 1.926 with a variance value of $48.153 \%$, personal dream factor has an eigenvalue of 1.007 with the variance value is $25,175 \%$, and the independence factor has an eigenvalue of 0,333 with a variance value of $8,319 \%$. The most dominant factor affecting the motivation of Undiksha Economics Education Department students for entrepreneurship is the freedom factor with varimax rotation of $48,153 \%$.

Keywords: entrepreneurial motivation, factor analysis. 


\section{PENDAHULUAN}

Transformasi

pengetahuan

berkewirausahaan telah berkembang pada dekade terahir ini. Demikian pula tren negara-negara lain termasuk indonesia, mata pelajaran atau mata kuliah kewirausahaan telah diajarkan di beberapa sekolah menengah atas kejuruan, dan berbagai perguruan tinggi, bahkan sebagai kurikulum wajib, serta berbagi kursus bisnis dan koperasi menjadi materi utama, bahkan menjadi salah satu konsentrasi di program studi tertentu (Saiman L. 2014).

Menurut PBB, suatu negara mampu untuk berkembang secara mandiri apabila jumlah wirausahawan di suatu negara minimal 2 persen dari total jumlah penduduk. Saat ini, jumlah wirausahawan di indonesia hanya sebesar 0,24 persen dari jumlah penduduk indonesia sebesar 238 juta jiwa. Jumlah tersebut lebih rendah jika dibandingkan dengan jumlah wirausaha di beberapa luar yang tingkat perekonomiannya lebih tinggi, seperti Amerika yang memiliki wirausaha sejumlah 4 persen dari total penduduknya, Singapura yang jumlah wirausahanya sebesar 7 persen dari jumlah penduduknya, dan Malaysa yang berjumlah wirausahanya mencapai 5 persen dari jumlah penduduknya. Menurut Made Dharmawati (2016), kewirausahaan merupakan padanan kata dari entrepreneurship dalam bahasa inggris, unternehmer dalam bahasa jerman, ondernemen dalam bahasa belanda. Seorang yang memiliki jiwa dan sikap wirausaha selalu tidak puas dengan apa yang telah dicapainya. Dari waktu-ke waktu, hari demi hari, minggu demi minggu selalu mencari peluang untuk meningkatkan usaha dan kehidupannya. la selalu berkreasi dan berinovasi tanpa berhenti, karena dengan berkreasi dan berinovasi lah semua peluang dapat diperolehnya.

Selain itu menurut llik dalam Dharmawati (2016). kita juga dapat meningkatkan skill para pekerja kita dengan adanya pelatihan-pelatihan kerja yang akan kita berikan kepada karyawan kita apabila kita dapat membuka lapangan pekerjaan buat orang lain. Tentunya ini menjadi kebanggaan untuk kita karena dapat berperan serta untuk membuka lapangan pekerjaan dan meningkatkan skill para pekerja. Disamping itu semua, enterpreneur juga bermanfaat untuk diri kita sendiri. Menjadi seorang entrepreneur harus memiliki sebuah mimpi yang besar untuk memulainya. Mimpi yang besar memotivasi diri kita untuk menggapai sebuah hal. Menurut Suryana dan Bayu (2011), kebanyakan orang merasa skeptis bila memikirkan menjadi entrepreneur, seperti besar kerugiannya bila rugi, dan lain-lain. Skeptis ini biasanya muncul bila kita merencanakan sesuatu hal dengan pertimbangan yang terlalu matang karena pemikiran kita meramalkan hal-hal buruk yang belum tentu terjadi sebagai bahan pertimbangan juga. Hal ini dapat dilawan dengan menjadikan mimpi kita sebesarbesarnya. Selain itu, kita lebih termotivasi berwirausaha bila didukung dengan kemampuan menyenangi bisnis. Dengan menjadi seorang entrepeneur kita dapat menuangkan ide-ide kita ke sesuatu yang lebih baik untuk memenuhi kebutuhan kita. Dan sebagai manfaat bagi diri kita sendiri, kita dapat menentukan patokan sendiri berapa keuntungan yang kita peroleh dalam bisnis kita sendiri.

Menurut Saiman (2014:26) "faktorfaktor yang mempengaruhi motivasi berwirausaha yaitu yang pertama laba: dapat menentukan berapa laba yang dikehendaki, keuntungan yang diterima, dan berapa yang akan dibayarkan kepada pihak lain atau pegawainya. Kedua kebebasan: bebas menetukan waktu, bebas dari supervisi, bebas aturan main yang menekan/intervensi, bebas dari aturan budaya organisasi/perusahaan. Ketiga impian personal: bebas mencapai standar hidup yang diharapkan, lepas dari rutinitas kerja yang membosankan karena harus mengikuti visi, misi, impian orang lain. Imbalan untuk menetukan nasib/visi, misi dan impiannya sendiri. Keempat kemandirian: memiliki rasa bangga, karena dapat mandiri dalam segala hal, seperti permodalan, mandiri dalam pengelolaan/ manajemen, mandiri dalam pengawasan, serta menjadi manajer terhadap dirinya sendiri."

Faktor laba berkaitan dengan seseorang melakukan kegiatan wirausaha 
agar dapat menentukan berapa laba yang di dikehendaki, keuntungan yang diterima, dan beberapa yang akan dibayarkan kepada pihak lain atau pegawai. Faktor kebebasan berkaitan dengan seseorang melakukan kegiatan wirausaha agar dapat bebas mengatur waktu, bebas dari supervisi, bebas dari aturan main yang menekan dan intervensi, serta bebas dari aturan budaya organisasi atau perusahaan. Faktor kebebasan berkaitan dengan seseorang melakukan kegiatan wirausaha agar bebas mencapai standar hidup yang diharapkan, lepas dari rutinitas kerja yang membosankan, karena harus mengikuti visi misi dan impian orang lain. Ini merupakan imbalan untuk menentukan nasib atau visi misi dan impian sendiri. Faktor kmandirian berkaitan dengan seseorang melakukan kegiatan wirausaha memiliki rasa bangga karena dapat mandiri dari segala hal, seperti permodalan, mandiri dalam pengelolaan atau manajemen, mandiri dalam pengawasan serta menjadi menejer terhadap diri sendiri. Dapat dikatakan bahwa berwirausaha mampu memotivasi seseorang untuk memperoleh laba, kebebasan, impian personal, dan kemandirian. Motivasi tersebut berupa keuntungan yang tidak akan didapat apabila bekerja disebuah industri atau bekerja dengan orang lain, karena dengan berwirausaha dapat menetukan labanya sendiri dan pendapatan akan datang setiap harinya tanpa perlu menunggu waktu gajian, dapat membuat aturan main sendiri, sebuah menentukan nasibnya sendiri lepas dari rutunitas kerja yang membosankan, serta memiliki kepuasan tersendiri karena mendapatkan pendapatan secara mandiri dari usaha yang didirikan sendiri.

Berdasarkan hasil observasi awal, dari 465 orang pada tahun 2018 mahasiswa ekonomi sebanyak 31 orang telah memiliki usaha sendiri. Bidang yang digeluti ada berbagai macam di antaranya yaitu online shop, penjual pulsa, konveksi, ketring, butik muslim dan lain-lain. Penelitian ini memilih Jurusan pendidikan ekonomi sebagai objeknya, karena Jurusan tidak hanya mempelajari tentang keguruan tetapi mata kuliahnya mempelajari tentang wirausaha yaitu hukum bisnis dan kewirausahaan. Dari wawancara yang peneliti lakukan pada mahasiswa pendidikan ekonomi, adanya banyak saingan dalam berwirausaha, jenis produk yang akan dijual sebagian besar sama dengan mahasiswa lainya sehingga mahasiswa binggung dalam menentukan jenis usaha apa yang akan dibangun. Masalah lainnya yaitu terdapat pada modal yang dimiliki mahasiswa. Dalam berwirausaha selain ide usaha, modal juga sebagai penentu berjalan tidaknya suatu ide usaha yang dimiliki mahasiswa. Sehingga dalam hal ini sangat diperlukan motivasi dalam berwirausaha. Inisiatif memulai dan mencari peluang diperlukan oleh mahasiswa.

Dari permasalahan diatas, maka penulis merasa perlu melakukan penelitian, dengan memilih judul "Faktor-Faktor yang Mempengaruhi Motivasi dalam Berwirausaha Pada Mahasiswa Pendidikan Ekonomi ."

\section{METODE}

$\begin{array}{ccc}\text { Penelitian ini dilakukan untuk } \\ \text { mengetahui } & \text { faktor-faktor } & \text { yang }\end{array}$ mempengaruhi motivasi mahasiswa untuk berwirausaha di pendidikan ekonomi dan mengetahui faktor yang dominan mempengaruhi motivasi mahasiswa untuk berwirausaha. Penelitian ini menggunakan rancangan penelitian faktorial.

Penelitian ini dilakukan di Jurusan Pendidikan Ekonomi FE Undiksha. Populasi adalah wilayah generalisasi yang terdiri dari obyek/subjek yang mempunyai kualitas dan karakteristik tertentu yang ditetapkan oleh peneliti untuk dipelajari dan kemudian ditarik kesimpulannya (Sugiyono, 2011). Populasi pada penelitian ini adalah mahasiswa Jurusan Pendidikan Ekonomi FE Undiksha yang berwirausaha sebanyak 31 orang. Sampel adalah bagian dari jumlah dan karakteristik yang dimiliki oleh populasi (Sugiyono, 2011). Apabila populasi kurang dari 100 orang, maka sebaiknya semua dijadikan sebagai sasaran penelitian. Oleh karena itu, penelitian ini merupakan penelitian populasi atau penelitian sampel jenuh, yang artinya semua populasi dijadikan sebagai sampel penelitian. Populasi pada penelitian ini adalah mahasiswa Jurusan Pendidikan Ekonomi FE Undiksha yang berwirausaha sebanyak 31 orang sehingga sampel dari 
penelitian ini juga berjumlah 31 orang . Jenis data yang digunakan dalam penelitian ini adalah data kuantitatif, yaitu data yang dapat dihitung. Dalam penelitian ini yang termasuk dalam data kuantitatif adalah data hasil jawaban kuesioner mengenai faktor-faktor yang mempengaruhi motivasi mahasiswa untuk berwirausaha. Sumber data yang digunakan adalah data primer. Data dikumpulkan secara langsung dari responden yang diperoleh dengan cara memberikan daftar pertanyaan yang berupa kuesioner mengenai faktor-faktor yang mempengaruhi motivasi mahasiswa untuk berwirausaha. Metode pengumpulan data yang digunakan dalam penelitian ini adalah kuesioner. Kuesioner merupakan suatu teknik pengumpulan data dalam penelitian dengan menggunakan angket yang berisi daftar pertanyaan kepada responden. Angket tersebut diberikan kepada para responden dan kemudian diharapkan setiap masing-masing responden akan mengisinya dengan pendapat dan persepsi setiap individu responden itu sendiri.

Angket diberikan langsung kepada responden, kemudian responden memilih salah satu dari alternatif jawaban yang telah tersedia. Kuesioner ditunjukan kepada mahasiswa Jurusan Pendidikan Ekonomi FE Undiksha yang berwirausaha. Instrumen penelitian digunakan berdasarkan konsep dasar dari teori yang mendasari dari variabel-variabel penelitian. Instrumen dalam penelitian ini terdiri dari pertanyaanpertanyaan dikembangkan dari indikator dengan masalah yang diteliti. Berdasarkan pada indikator yang terdapat di dalam jabaran variabel, maka dapat disusun dan dikembangkan menjadi instrumen penelitian yang berupa kuesioner atau angket. Skala pengukuran yang digunakan adalah skala Likert dengan lima alternatif jawaban. Variabel dalam penelitian yang telah ditetapkan akan dijabarkan menjadi indikator, dan dari indikator ini kemudian dijabarkan sebagai titik tolak untuk menyusun item intrumen yang kemudian diubah dalam beberapa pertanyaan yang selanjutnya dijawab oleh responden.

Kuesioner sebagai instrumen pengumpulan data terlebih dahulu harus diuji tingkat validitas dan reliabilitasnya. Data yang didapat dari kuesioner adalah data ordinal. Agar dapat diuji, maka data tersebut diubah menjadi data interval melalui Method of Successive Interval dengan bantuan program Microsoft Office Excel 2007. Untuk menguji tingkat validitas dan reliabilitas instrumen penelitian akan diujikan kepada 30 responden. Uji validitas digunakan untuk mengukur valid tidaknya suatu kuesioner. Kuisioner dikatakan valid apabila kuisioner mampu untuk mengungkapkan dengan pasti apa yang akan diteliti. Pengujian validitas dalam penelitian ini dilakukan dengan menggunakan korelasi Corrected Item-Total Correlation yang terdapat dalam program SPSS 24.0 for Windows. Suatu pertanyaan dikatakan valid jika $r_{\text {hitung }}>r_{\text {tabel }}$ dan kuisioner dikatakan tidak valid apabila $r_{\text {hitung }}$ $<r_{\text {tabel. }}$. Reliabilitas menunjuk pada satu pengertian bahwa suatu instrumen cukup dapat dipercaya untuk digunakan sebagai alat pengumpulan data karena instrumen tersebut sudah baik. Dalam penelitian ini pengujian reliabilitas instrumen dilakukan dengan membandingkan nilai Cronbach Alpha yang diperoleh dari SPSS 24.0 for Windows dengan batas nilai Crombach Alpha untuk mengukur instrumen yang reliabel. Pengujian statistik dengan menggunakan teknik statistik Cronbach Alpha instrumen dikatakan reliabel untuk mengukur variabel apabila memiliki nilai Cronbach Alpha lebih $>0,60$. Hasil uji validitas pada kuesioner laba 7 item dinyatakan valid, kuesioner kebebasan 10 item dinyatakan valid, kuesioner impian personal 6 item dinyatakan valid, dan kuesioner kemandirian 8 item dinyatakan valid. Hasil uji reliabilitas menunjukan kuesioner laba, kebebasan, impian personal, dan kemandirian memiliki Alpha Cronbach > 0,60 sehingga kuesioner laba, kebebasan, impian personal, dan kemandirian dinyatakan reliabel.

Sesuai dengan rumusan masalah, tujuan penelitian dan juga jenis data yang dikumpulkan, maka metode analisis data yang digunakan dalam penelitian ini adalah model analisis faktor. Metode analisis faktor merupakan metode yang digunakan untuk mereduksi data atau meringkas dari variabel yang banyak diubah menjadi variabel yang jumlahnya lebih sedikit (Sulianto, 2012). Analisis faktor digunakan 
untuk mereduksi dan meringkas dari banyak variabel ke dalam satu atau beberapa faktor, dengan menggunakan program SPSS 24.0 for Windows. Dalam analisis faktor terdiri lima tahap, yaitu sebagai berikut. Pertama, semua data yang masuk dan diolahakan mengahasilkan matrik korelasi. Matrik korelasi dapat diidentifikasi variabel-variabel tertentu yang tidak mempunyai korelasi dengan variabel yang lain, sehingga dapat dikeluarkan dari analisis. Untuk menguji ketepatan model analisis faktor, maka dapat digunakan Barlett's test of Sphericity yang dipakai untuk menguji bahwa variabel-variabel dalam sampel berkolerasi. Hasil Barlett's test of Sphericity menunjukan apakah hubungan antara variabel-variabel signifikan atau tidak. Statistik lain yang berguna adalah pengukuran kelayakan sampai Kaiser Meyer Olkin (KMO). Analisis faktor dianggap layak jika besaran KMO nilainya minimal 0,50. Besaran ini digunakan untuk mengukur derajat korelasi antara variabel dengan Kriteria Mesure of Sampling Adequacy (MSA) $\geq 0,50$. Kedua, menentukan jumlah faktor. Variabel disusun kembali berdasarkan pada korelasi hasil langkah pada butir dua untuk menentukan faktor yang diperlukan untuk mewakili data. Untuk menntukan berapa faktor yang dapat diterima secara empiric dapat dilakukan berdasarkan besarnya eigenvalue setiap faktor yang muncul. Semakin besar eigenvalue setiap faktor, semakin representatif faktor faktor tersebut untuk mewakili sekelompok variabel. Faktor-faktor ini dipilih adalah faktor yang mempunyai eigenvalue sama dengan atau lebih dari satu. Ketiga, rotasi faktor. Hasil penyederhanaan faktor dalam marik faktor memperlihatkan hubungan antara faktor dengan variabel individu, tetapi dalam faktor-faktor tersebut terdapat banyak variabel yang berkorelasi sehingga sulit diinterpretasikan. Dengan menggunakn rotasi faktor matrik, matrik faktor ditranspormasikan ke dalam matrik yang lebih sederhana sehinga mudah untuk diinterpretasikan. Dalam perilaku ini digunakan rotasi varimax. Keempat, interprestasi faktor. Interprestasi faktor dilakukan dengan mengelompokan variabel yang mempunyai faktor loading tinggi ke dalam faktor tersebut. Untuk menginterpretasikan hasil penelitian ini faktor loading minimal 0.5 . Variabel yang mempunyai faktor loading kurang dari 0,5 dikeluarkan dari model. Kelima, mentukan penetapan model. Tahap terahir dari analisis faktor adalam mengetahui apakah model mampu menjelaskan dengan baik. Fenomena yang ada perlu diuji dengan teknik Princapal Component Analisis, yaitu dengan melihat jumlah residual antara korelasi yang diamati dengan korelasi yang direproduksi, dalam penelitian ini, tuk mempermudah proses perhitungan dan untuk mendapatka hasil perhitungan yang akurat dalam analisis data, penelitian mengunakan bantuan alat hitung berupa program SPSS 24.0 for Windows. Data yang didapat dari kuesioner masih berupa data ordinal, sedangakan analisis data yang dipakai untuk membuktikan kebenaran pengujian analisis faktor mengisyaratkan minimal data interval, maka data ordinal tersebut perlu ditingkatkan skala pengukuarannya menjadi skala interval melalui "Method of Succestive Interval".

Hipotesi konseptual akan dianalisis dengan menggunakan analais faktor dengan langkah-langkah sebagai berikut. Pertama, menguji matrik korelasi dengan mengunakan Barlett's Sphericity dengan koefisien KMO yang telah tersedia dalam SPSS 24.0 for Windows. Jika hasil pengujian statistik Barlett's Sphericity signifikan dan hasil perhitungan koefisien $\mathrm{KMO}>0,5$. maka persyaratan pengujian analisis faktor untuk menentukan faktor yang menjelaskan komponen utama yang memiliki parameter karakteristik terkecil (eigenvalue). Kedua, untuk menetukan dimensi atau faktor kebrhasilan usaha yang paling mendominasi pada faktor maka digunakan parameter koefisien varimax rotation dari dimensi atau faktor keberhasilan usaha yang paling mendekati +1 atau mendekati -1 .

\section{HASIL DAN PEMBAHASAN}

Berdasarkan hasil analisis data menunjukkan bahwa faktor-faktor yang mempengaruhi motivasi mahasiswa Pendidikan Ekonomi Undiksha untuk berwirausaha dapat dijelaskan oleh persentase dari masing-masing faktor. Nilai 
Total Variance Explained digunakan untuk mengetahui persentase dari 4 faktor yang dianalisis, yaitu laba, kebebasan, impian personal, dan kemandirian. Hasil analisis faktor menggunakan bantuan program SPSS 24.0 for Windows, dimana persentase dari masing-masing faktor dapat dilihat pada tabel
1.

Tabel 1. Hasil Analisis Total Variance Explained Total Variance Explained

\begin{tabular}{|c|c|c|c|c|c|c|}
\hline \multirow[t]{2}{*}{ Component } & \multicolumn{3}{|c|}{ Initial Eigenvalues } & \multicolumn{3}{|c|}{$\begin{array}{l}\text { Extraction Sums of } \\
\text { Squared Loadings }\end{array}$} \\
\hline & Total & $\%$ of Variance & Cumulative \% & Total & $\%$ of Variance & Cumulative \% \\
\hline 1 & 0,734 & 18,353 & 18,353 & & & \\
\hline 2 & 1,926 & 48,153 & 66,506 & 1,926 & 48,153 & 48,153 \\
\hline 3 & 1,007 & 25,175 & 91,681 & 1,007 & 25,175 & 73,328 \\
\hline 4 & 0,333 & 8,319 & 100,000 & & & \\
\hline
\end{tabular}

Extraction Method: Principal Component Analysis.

Berdasarkan tabel 1 dapat ditunjukkan bahwa faktor laba memiliki eigenvalue sebesar 0,734 dengan nilai varian sebesar $18,353 \%$, faktor kebebasan memiliki eigenvalue sebesar 1,926 dengan nilai varian sebesar 48,153\%, faktor impian personal memiliki eigenvalue sebesar 1,007 dengan nilai varian sebesar $25,175 \%$, dan faktor kemandirian memiliki eigenvalue sebesar 0,333 dengan nilai varian 8,319\%.

Faktor yang dapat menjelaskan motivasi mahasiswa Pendidikan Ekonomi Undiksha untuk berwirausaha dapat ditunjukkan dengan ekstraksi faktor. Ekstraksi faktor dapat dijelaskan oleh total persentase dari masing-masing faktor utama. Faktor-faktor utama tersebut adalah kebebasan dan impian personal yang memiliki eigenvalue $>1$. Untuk mengetahui distribusi dimensi-dimensi yang belum dirotasi ke dalam faktor yang telah terbentuk, maka dapat dilihat pada Rotated Component Matrix. Faktor yang mampu menjelaskan motivasi mahasiswa Pendidikan Ekonomi Undiksha untuk berwirausaha dapat dilihat pada tabel 2 .

Tabel 2. Faktor yang Menjelaskan Motivasi Mahasiswa Pendidikan Ekonomi Undiksha Untuk Berwirausaha

\begin{tabular}{|c|c|}
\hline Eigenvalues & $\begin{array}{c}\text { Variance } \\
\text { Explained (\%) }\end{array}$ \\
\hline $\begin{array}{l}\text { Kebebasan } \\
\text { Impian personal }\end{array}$ & $\begin{array}{l}48,153 \\
25,175\end{array}$ \\
\hline $\begin{array}{l}\text { Berdasarkan tabel } 2 \text { dapat ditunjukkan } \\
\text { bahwa faktor yang memiliki eigenvalue }>1 \\
\text { adalah faktor kebebasan dan impian } \\
\text { personal. Nilai varianced explained faktor } \\
\text { kebebasan sebesar } 48,153 \% \text { dan faktor } \\
\text { impian personal sebesar } 25,175 \% \text {. Total } \\
\text { nilai varianced explained dari kedua faktor } \\
\text { keseluruhan mampu menjelaskan sebesar } \\
73,328 \% \text {. Dengan demikian, } 73,328 \% \text { dari } \\
\text { seluruh variabel yang ada dapat dijelaskan } \\
\text { oleh } 2 \text { faktor yang terbentuk. Faktor } \\
\text { kebebasan memiliki varianced explained } \\
48,153 \% \text { artinya faktor kebebasan } \\
\text { mempengaruhi motivasi mahasiswa }\end{array}$ & $\begin{array}{l}\text { Pendidikan Ekonomi Undiksha untuk } \\
\text { berwirausaha sebesar 48,153\%. Faktor } \\
\text { impian personal memiliki varianced } \\
\text { explained } 25,175 \% \text {, artinya faktor impian } \\
\text { personal mempengaruhi motivasi } \\
\text { mahasiswa Pendidikan Ekonomi Undiksha } \\
\text { untuk berwirausaha sebesar 25,175\%. } \\
\text { Penentuan nama faktor yang telah } \\
\text { terbentuk untuk masing-masing faktor } \\
\text { bersifat subjektif, sebagian besar variabel } \\
\text { yang memiliki nilai loading factor tertinggi } \\
\text { digunakan untuk memberi nama faktor. } \\
\text { Untuk melihat nilai loading factor dapat } \\
\text { dilihat tabel } 3 .\end{array}$ \\
\hline
\end{tabular}




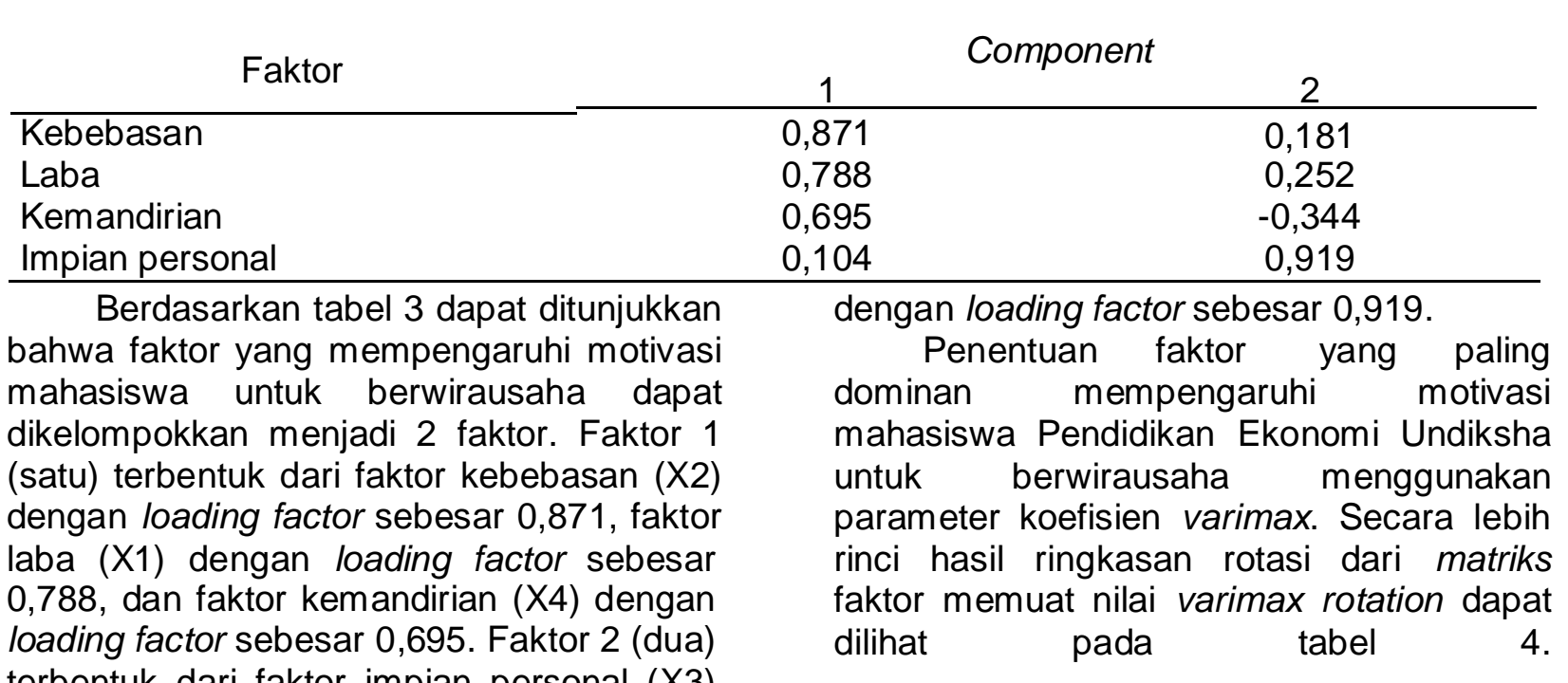
terbentuk dari faktor impian personal (X3)

Tabel 4. Matriks Rotasi Hasil Anallisis Faktor

Faktor Mempengaruhi Motivasi Mahasiswa

\begin{tabular}{l} 
Untuk Berwirausaha \\
\hline Kebebasan \\
Impian personal
\end{tabular}

Berdasarkan tabel 4 dapat ditunjukkan bahwa faktor yang paling dominan mempengaruhi motivasi mahasiswa Pendidikan Ekonomi Undiksha untuk berwirausaha adalah faktor kebebasan dengan varimax rotation sebesar $48,153 \%$.

Faktor-faktor yang mempengaruhi motivasi mahasiswa Pendidikan Ekonomi Undiksha untuk berwirausaha adalah laba, kebebasan, impian personal, dan kemandirian. Hal ini sesuai dengan teori yang dikemukakan oleh Saiman (2014) bahwa terdapat empat faktor yang memotivasi seseorang untuk menjadi wirausaha, yaitu: laba, kebebasan, impian personal, dan kemandirian. Hasil penelitian ini didukung oleh penelitian yang dilakukan oleh Marpaung dan Wardhana (2017), yang menyatakan bahwa faktor-faktor yang memotivasi mahasiswa administrasi bisnis angkatan 2013 Universitas Telkom untuk berwirausaha adalah faktor kebebasan, kemandirian, impian personal, dan laba. Dengan demikian untuk menjelaskan yang mempengaruhi motivasi mahasiswa Varimax Rotation (\%)

$\begin{array}{cc}(1) & (2) \\ 48,153 & - \\ - & 25,175\end{array}$

Pendidikan Ekonomi Undiksha untuk berwirausaha dapat dilihat dari faktor laba, kebebasan, impian personal, dan kemandirian.

Faktor kebebasan merupakan faktor yang paling dominan mempengaruhi motivasi mahasiswa Pendidikan Ekonomi Undiksha untuk berwirausaha. Faktor kebebasan paling dominan dibandingkan faktor yang lain disebabkan karena kebebasan dapat memberikan kesempatan bagi mahasiswa untuk melakukan kegiatan wirausaha agar dapat bebas mengatur waktu, bebas dari supervisi, bebas dari aturan main yang menekan dan intervensi, serta bebas dari aturan budaya organisasi atau perusahaan. Hal ini sesuai dengan kondisi pengusaha yang juga memiliki kewajiban sebagai mahasiswa di kampus sehingga dapat mengatur waktu untuk menjalankan usahanya. Hal ini sesuai dengan pendapat Mopangga (2014), yang menyatakan bahwa kecenderungan tingginya minat wirausaha mahasiswa karena adanya perasaan lebih bebas bila 
berwirausaha, senang bekerja menurut intuisi pribadi, keyakinan pada kemampuan dan potensi diri, serta keberanian menerima tantangan dan mengambil risiko. Hasil penelitian ini didukung oleh penelitian yang dilakukan oleh Marpaung dan Wardhana (2017), yang menyatakan bahwa faktor dominan yang memotivasi mahasiswa administrasi bisnis angkatan 2013 Universitas Telkom untuk berwirausaha adalah faktor kebebasan.

Impian personal juga merupakan faktor penting dalam mempengaruhi motivasi mahasiswa Pendidikan Ekonomi Undiksha untuk berwirausaha. Hal ini disebabkan karena impian personal menjadi cita-cita atau harapan yang dapat menjadi pendorong kuat bagi seseorang untuk berwirausaha. Impian personal dapat menentukan nasib atau visi misi dan impian sendiri untuk mwujudkan jenis usaha yang dijalankan mahasiswa. Hal ini sesuai dengan pendapat Saiman (2014), yang menyatakan bahwa salah satu faktor yang memotivasi seseorang untuk menjadi wirausaha, yaitu: impian personal. Hasil penelitian ini didukung oleh penelitian yang dilakukan oleh Juanisa (2015), yang menyatakan bahwa tingginya tingkat motivasi berwirausaha mahasiswa dipengaruhi faktor impian personal.

\section{SIMPULAN DAN SARAN Simpulan}

Berdasarkan hasil analisis data dan pembahasan hasil penelitian maka dapat ditarik simpulan sebagai berikut. Pertama, faktor-faktor yang mempengaruhi motivasi mahasiswa Pendidikan Ekonomi Undiksha untuk berwirausaha adalah faktor laba memiliki eigenvalue sebesar 0,734 dengan nilai varian sebesar $18,353 \%$, faktor kebebasan memiliki eigenvalue sebesar 1,926 dengan nilai varian sebesar $48,153 \%$, faktor impian personal memiliki eigenvalue sebesar 1,007 dengan nilai varian sebesar $25,175 \%$, dan faktor kemandirian memiliki eigenvalue sebesar 0,333 dengan nilai varian sebesar $8,319 \%$. Kedua, faktor yang paling dominan mempengaruhi motivasi mahasiswa Pendidikan Ekonomi Undiksha untuk berwirausaha adalah faktor kebebasan dengan varimax rotation sebesar $48,153 \%$.

\section{Saran}

Berdasarkan simpulan diatas, maka dapat dikemukakan beberapa saran sebagai berikut. Pertama, Bagi mahasiswa yang memiliki minat untuk berwirausaha disarankan dalam memilih usaha yang akan dijalani dengan mempertimbangkan beberapa faktor agar tetap termotivasi, yaitu (a) laba, contohnya dengan cara memilih usaha yang fleksibel dan bebas dalam hal menentukan laba/keuntungan yang ingin di capai, (b) kebebasan, contohnya mahasiswa dapat berinovasi dan berkreativitas dalam berwirausaha dengan bebas dan juga mahasiswa bebas mengatur jam kerja, (c) impian personal, contohnya memilih jenis usaha yang nantinya dapat mencapai standar hidup yang lebih tinggi, (d) kemandirian, contohnya memilih jenis usaha yang secara mandiri dapat dilakukan pengawasan terkait dengan aktivitas kewirausahaan yang dijalankan. Kedua, kepada mahasiswa untuk memfokuskan memilih jenis usaha yang memberikan kebebasan dalam berkreativitas dan berinovasi, dimana dapat bebas menuangkan ide-ide yang kreatif agar usaha yang dibuat bisa berkembang sesuai dengan keinginan, dan dapat membuat jadwal kerja yang fleksibel, dan juga dapat dengan bebas membuat aturanaturan yang sesuai dengan prinsip mahasiswa dalam menjalankan usaha. Ketiga bagi peneliti lain yang mendalami mengenai faktor-faktor yang mempengaruhi motivasi mahasiswa untuk berwirausaha diharapkan menggunakan objek yang berbeda guna keberlakuan temuan ini secara lebih luas. Selain itu, penelitian ini perlu dikembangkan dengan mengkaji faktor-faktor lain yang mempengaruhi motivasi mahasiswa untuk berwirausaha.

\section{DAFTAR PUSTAKA}

Buchari, Alma. 2016. Kewirausahaan untuk Mahasiswa dan Umum. Bandung: Alfabeta.

Dharmawati, Made. 2016. Kewirausahaan. Jakarta: PT Raja Grafindo Persada. 
Fahmi, Irham. 2014. Kewirausahaan. Bandung: Alfabeta.

llik, Matrawijaya E. 2010. Bisnis Jamur Tiram di Rumah Sendiri. Bogor: IPB Press.

Juanisa, Nur Atika. 2015. Pengaruh Tingkat Motivasi Berwirausaha Terhadap Sikap Keberlanjutan Usaha (Studi Pada Mahasiswa Fakultas Ekonomi Bisnis dan Fakultas Komunikasi Bisnis Universitas Telkom Pasca Mata Kuliah Entrepreneurship). Skripsi. Manajemen Bisnis Telekomunikasi dan Informatika, Fakultas Ekonomi Bisnis, Universitas Telkom.

Marpaung, Loviana L. dan Wardhana, Aditya. 2017. Analisis Faktor Motivasi Berwirausaha Mahasiswa Administrasi Bisnis Angkatan 2013 Universitas Telkom. eProceedings of Management, 4(1), 909-914.

Mopangga, Herwin. 2014. Faktor Determinan Minat Wirausaha Mahasiswa Fakultas Ekonomi dan Bisnis Universitas Negeri Gorontalo. Trikonomika, 13(1), 78-90.

Saiman, L. 2014. Kewirausahaan, Teori, Praktik, dan Kasus-kasus. Jakarta: Salemba Empat.

Sugiyono. 2011. Metode Penelitian Kuantitatif Kualitatif dan $R \& D$. Bandung: Alfabeta.

Suliyanto. 2012. Analisis Data Dalam Aplikasi Pemasaran. Bogor: Ghalia Indonesia.

Suryana, Y. dan Bayu, K. 2010. Kewirausahaan Pendekatan Karakteristik Wirausahawan Sukses. Jakarta: Kencana. 